\title{
Seed phytate content and phosphorus uptake and distribution in dry bean genotypes
}

\author{
Cileide Maria Medeiros Coelho ${ }^{1}$, Júlio Cesar Pires Santos ${ }^{2}$, Siu Mui Tsai ${ }^{1}$ and Victor Alexandre Vitorello ${ }^{1, *}$
}

${ }^{1}$ Laboratório de Biologia Celular e Molecular, Centro de Energia Nuclear na Agricultura, Universidade de São Paulo, CP 96, 13400970, Piracicaba, SP, Brasil; ${ }^{2}$ Universidade do Estado de Santa Catarina, CP 281, 88.520-000, Lages, SC, Brasil; * Corresponding author:victor@cena.usp.br

Phytic acid is the major storage form of phosphorus in seeds of legumes and cereals. Since phytate can form complexes with proteins and minerals, reducing the digestive availability of these nutrients, it is usually regarded as an antinutrient, although recent work indicates that it has important beneficial roles as an antioxidant and anticarcinogen. Therefore, there is an interest in the assessment and manipulation of phytate contents in important food grains such as beans. The objective of this work was to compare eleven dry bean genotypes with regard to grain contents of $\mathrm{P}$, phytate, inorganic $\mathrm{P}$ and protein and to examine if differences between genotypes could be explained by differences in grain protein content or in uptake and partitioning of P. Plants were grown in a greenhouse in pots containing soil and commercial substrate amended with 7.4 and $37 \mathrm{mg} \mathrm{P.dm}{ }^{-3}$. The experimental setup was a random, complete block design with five replications. Genetic variability in grain phytate contents was observed. At the higher dose of $\mathrm{P}$ fertilization, genotype Una presented the highest phytate content (1.48\%) and the highest fraction of $\mathrm{P}$ as phytate ( $72 \%$ ), whereas these features were lowest in Paraiso (0.70\% and $47 \%$, respectively). Inorganic P made up $8 \%$ of total $\mathrm{P}$ in Paraiso. A correlation between phytate and protein contents among genotypes was significant $(\mathrm{r}=0.73)$ only under the higher dose of $\mathrm{P}$ fertilization. With the exception of genotype 4AP, differences in phytate content could not be explained by differences in uptake and partitioning of $\mathrm{P}$ in the plant. In the case of Paraiso, it is inferred that the lower phytate contents were due to differences in the metabolism of $\mathrm{P}$ and dry matter accumulation in the grain.

Key words: Inorganic phosphorus, Phaseolus, phytic acid, protein.

Teor de fitato em grãos e a absorção e distribuição de fósforo em genótipos de feijoeiro: $\mathrm{O}$ fitato é a principal forma de fósforo nos grãos de cereais e leguminosas. Sua presença pode diminuir o aproveitamento digestivo de diversos nutrientes, embora recentemente tem sido demonstrado que também tem efeitos benéficos, podendo atuar como anti-oxidante e anti-carcinogênico. Portanto, há um interesse na avaliação e na manipulação dos teores de fitato em grãos. O objetivo deste trabalho foi comparar onze genótipos de feijoeiro quanto ao teor de fitato, $\mathrm{P}$, fósforo inorgânico e proteína nos grãos e examinar se a absorção e distribuição do $\mathrm{P}$ em diferentes partes da planta ou o teor de proteína no grão poderiam explicar as diferenças encontradas. As plantas foram conduzidas em casa de vegetação, em baldes contendo uma mistura de solo e substrato comercial que recebeu 7,4 e $37 \mathrm{mg} \mathrm{P.dm}^{-3}$. Encontrou-se variabilidade genética quanto ao teor de fitato nos grãos. Na dose mais alta de $\mathrm{P}$ a variedade Una apresentou maior teor de fitato (1,48 \%), correspondendo a $72 \%$ do P do grão. A variedade com menor teor de fitato foi Paraiso com $0,70 \%$, correspondente a 47 \% do P dos grãos. O P inorgânico contribuiu em 8 \% do P em Paraiso. A correlação entre fitato e proteína foi alta $(r=0,73)$ apenas na dose mais alta de P. Com exceção do genótipo 4AP, esta variação não pôde ser explicada por diferenças na absorção e distribuíção do P na planta. No caso de Paraíso, infere-se que o menor teor de fitato foi devido as diferenças no metabolismo do P e no acúmulo de matéria seca nos grãos.

Palavras-chave: ácido fítico, fósforo inorgânico, Phaseolus, proteína. 


\section{INTRODUCTION}

Phytic acid (myo-inositol hexakisphosphate) is the major storage form of phosphorus (P) in seeds of legumes and cereals (Reddy et al., 1989). Current literature suggests that phytic acid occurs primarily as potassium and magnesium salts in dry beans (Phaseolus vulgaris L.) and calcium and potassium salts in soybeans (Glycine max) (Cheryan, 1980). In this anionic form, phytate can form complexes with proteins and minerals, leading to decreased availability of these nutrients in the digestive tract (Cheryan, 1980). Thus, phytate is generally regarded as an antinutrient. On the other hand, phytate may play an important role as an antioxidant by complexing iron and thereby reducing free radical generation and the peroxidation of membranes, and may also act as an anticarcinogen, providing protection against colon cancer (Graf et al., 1987; Thompson and Zhang, 1991). Therefore, interest in the assessment and manipulation of phytate contents in grains is increasing worldwide. This is particularly important in Brazil, where soybeans and beans are important grain crops. However, the regulatory control of phytic acid synthesis in developing seeds is poorly understood.

On a broad level, phytate synthesis can be regulated in two ways. First, by the amount of photoassimilates and phosphorus translocated to the grain. Second, by the partitioning of these substrates among different pools and competing metabolic pathways in the developing grain. As an example of the first case, it has been shown that phytate levels are correlated with the supply of P to the plant and with the content of inorganic phosphorus in leaves (Raboy and Dickinson 1984a; Raboy and Dickinson, 1993), which ultimately leads to increased translocation of $\mathrm{P}$ to the grain. Another important factor seems to be the protein content of grains, since a correlation between phytate and protein contents has frequently been found (Raboy et al., 1991). This is not entirely surprising given the association between protein and phytate in protein storage bodies, but the regulatory mechanisms are entirely unknown.

Although the phytate content of seeds depends to a large extent on the environment, such as the supply of phosphorus to the plant (Raboy and Dickinson, 1993; Buerkert et al., 1998), which has also been shown in beans (Griffiths and Thomas, 1981; Coelho, 1998; Santos, 1998), there is important genetic variability in the phytate content of beans and it appears to be a trait controlled by several genes. In a field study undertaken with twenty soybean varieties, seed phytic acid concentrations ranged from 18.8 to 27.7 g. $\mathrm{Kg}^{-1}$ (Raboy et al., 1984b). Other researchers estimated the heritability of phytate content to be $81 \%$, demonstrating the feasibility of breeding for this trait (Mebrahtu et al., 1997). Although there have been a few reports in the literature (Miranda et al., 1994; Ribeiro et al., 1999), very little is known with regard to phytate contents in beans or soybeans grown in Brazil.

Differences in genotypes with regard to phytate content in beans should prove useful in elucidating the regulatory control of phytate synthesis. Thus, the objective of this work was to compare eleven bean genotypes with regard to $\mathrm{P}$ uptake and distribution, grain protein content and the distribution of $\mathrm{P}$ among different fractions in the grain, particularly phytate. This paper is a part of ongoing research attempting to understand the physiological and biochemical mechanisms involved in the regulation of phytic acid biosynthesis during the development of bean grains.

\section{MATERIAL AND METHODS}

The commercial bean varieties Rio tibagi, Una, Carioca, IAPAR 65, Pyatã, Diamante negro and Aruã were used. Their seeds were supplied by the Experimental Research Station of the Instituto Agronômico de Campinas, in Capão Bonito, state of São Paulo. The other varieties were Paraiso, 4AP, 40AP and 13BP, landraces grown in the state of Santa Catarina, and their seeds were supplied by the Active Bean Germplasm Bank of the Universidade do Estado de Santa Catarina.

Plants were grown in a greenhouse in $10-\mathrm{L}$ pots containing $8 \mathrm{~L}$ of a $4: 1(\mathrm{v} / \mathrm{v})$ mixture of soil and commercial substrate (Plantmax from Eucatex). An acid, dystrophic soil, with low levels of nutrients and P (2 mg P. $\left.\mathrm{dm}^{-3}\right)$, was collected and amended with lime at $3.8 \mathrm{~g} . \mathrm{dm}^{-3}$, according to chemical analysis, so as to reach a base saturation of about $70 \%$. Prior to planting, phosphorus, nitrogen and potassium were applied to the mixture at two doses: 7.4, 3.4 and 14.1 or 37,17 and $70.4 \mathrm{mg} \cdot \mathrm{dm}^{-3}$ of $\mathrm{P}, \mathrm{N}$ and $\mathrm{K}$, respectively. These doses were chosen as an approximation of those used in low and high-yielding commercial production of beans. At 25 and 35 days after planting, each pot received $27.5 \mathrm{mg} \mathrm{N} \mathrm{dm}^{-3}$, and $250 \mathrm{ml}$ of a nutrient solution modified from Sarruge (1975). The experimental setup was a random complete block design with five replications. Each replicate consisted of one pot with one plant. 
At maturity, shoots, roots, pods and seed were harvested. Roots were harvested by gently shaking off the soil mixture and several washes over a sieve. All samples were dried in a forced-air oven $\left(60{ }^{\circ} \mathrm{C}\right.$ for $\left.72 \mathrm{~h}\right)$, except the seeds, which were freeze-dried and ground in a Wiley mill to pass a 40 mesh screen. Samples were stored at room temperature in a dry and ventilated place.

Phosphorus content was determined colorimetrically following nitric/perchloric acid digestion, using the metavanadate method, which is based on the formation of a yellow vanadomolibdofosforic complex as described by Malavolta et al. (1989). To determine phytate, the method of Latta and Eskin (1980) was employed. A 500-mg sample was extracted with $20 \mathrm{~mL}$ of $2.4 \% \mathrm{HCl}(0.65 \mathrm{~N})$ for $2 \mathrm{~h}$ at room temperature on a rotary shaker. The extract was centrifuged $\left(10,000 g_{\mathrm{n}}, 15 \mathrm{~min}\right)$ and the supernatant decanted and filtered through Whatman number 1 filter paper. A 3 $\mathrm{mL}$ aliquot of the filtrate was diluted to $18 \mathrm{~mL}$ with distilled water, and the diluted sample was passed through a 200-400 mesh AG1-X8 chloride anion exchange resin, taking care so that no more than $3 \mathrm{mg}$ phytate per $1.0 \mathrm{~g}$ of resin was applied. Inorganic phosphorus was eluted with $0.07 \mathrm{M} \mathrm{NaCl}$ followed by elution of phytate with $0.7 \mathrm{M}$ $\mathrm{NaCl}$. Phytate was determined colorimetrically, based on the pink color of the Wade reagent, which is formed upon the reaction of ferric ion and sulfosalicylic acid, and has an absorbance maximum at $500 \mathrm{~nm}$. In the presence of phytate, the iron is sequestered and unavailable to react with sulfosalicylic acid, resulting in a decrease in pink color intensity.

The extraction procedure employed for determination of inorganic P (Pi) was as proposed by Raboy and Dickinson (1984a). To determine Pi, $100 \mathrm{mg}$ of sample was extracted twice, for two minutes, with $4 \mathrm{~mL}$ of $12.5 \%$ trichloroacetic acid (w/v) in $0.025 \mathrm{M} \mathrm{MgCl}_{2}$ in a cold mortar. Each extract was centrifuged at $10,000 g_{\mathrm{n}}$ for $10 \mathrm{~min}$ and filtered through Whatman number 1 filter paper. The filtered extracts were combined, diluted to $12.5 \mathrm{~mL}$ and $\mathrm{Pi}$ was determined colorimetrically, as proposed by Chen et al. (1956).

Protein content was determined by total $\mathrm{N}$ content of the sample, where \% Protein $=\mathrm{N}$ content $(\%) \times 6.25$. Samples $(200 \mathrm{mg})$ were placed in $75 \mathrm{~mL}$ digestion tubes and $6 \mathrm{~mL}$ of digestion mixture, consisting of concentrated sulfuric acid, hydrogen peroxide $30 \%$, lithium sulfate 14 $\%$ and selenium $42 \%$, was added to each sample. The samples were placed in a digestion block until samples became clear at a temperature of $250{ }^{\circ} \mathrm{C}$. Samples were diluted with water to $75 \mathrm{~mL}$. Three $\mathrm{mL}$ aliquots were diluted and analyzed in a flow-through colorimeter for $\mathrm{N}$ determination. The $\mathrm{N}$ content of samples was quantified according to Parkinson and Allen (1975), which utilizes the colorimetric determination of ammonium as a blue indophenol complex formed when ammonia reacts with sodium phenate and hypochlorite.

\section{RESULTS AND DISCUSSION}

Grain phosphorus content differed among the genotypes grown under the higher dose of fertilizer $P$ and ranged from 0.4 to $0.6 \%$, similar to results found in the literature (Lolas and Markakis, 1975). Grains from genotype Una presented the highest values of $\mathrm{P}$ content while Paraiso presented the lowest. However, Paraiso did not differ statistically from Diamante negro, Pyatã and 4AP, and Una did not differ from the remaining genotypes. Under lower $\mathrm{P}$ supply, differences in seed $\mathrm{P}$ content between genotypes were not significant (figure 1).

The grain phytate contents of genotypes 40AP, 13BP, Una and Diamante Negro were higher than Paraiso under the lower dose of fertilizer P (figure 2). However, differences in phytate content among genotypes were more pronounced under higher doses of $\mathrm{P}$, in which Una presented the highest value and Paraiso the lowest. Paraiso did not differ statistically only from genotypes Diamante Negro, 4AP, 40AP and Rio tibagi (figure 2). Hence, genetic variability was observed in the phytate content of the bean grains, with values ranging from 0.7 to $1.48 \%$. In a field study undertaken with twenty soybean varieties, seed phytic acid concentrations ranged from 18.8 to $27.7 \mathrm{~g}$. $\mathrm{Kg}^{-1}$ (Raboy et al., 1984b). Phytate contents of fourteen soybean cultivars grown in Brazil ranged from 0.56 to $1.20 \%$ (Miranda et al., 1994). Two other Brazilian soybean cultivars were found to have phytic acid contents of 1.30 and $1.67 \%$ (Ribeiro et al., 1999). Other authors have reported variation in phytate content in other crops, such as maize (Ertl et al., 1998) and wheat (Raboy et al., 1991).

In general, phytate contents in grains are higher with increases in supply of P (Raboy and Dickinson, 1993). This effect was also observed with the genotypes evaluated in this study, although it was less pronounced than expected. Phytate content in the bean grains increased $10 \%$ with the higher dose of $\mathrm{P}$ fertilization. 


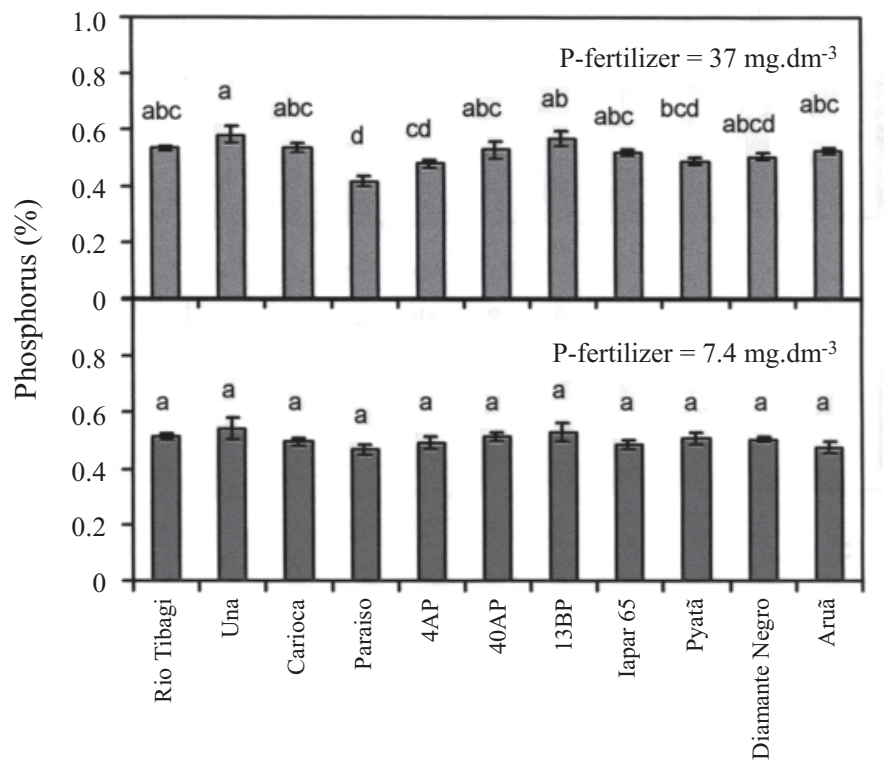

Genotypes

Figure 1. Phosphorus content in grains of bean genotypes grown under two doses of $\mathrm{P}$ fertilization. Phosphorus was applied at 7.4 and $37 \mathrm{mg} \cdot \mathrm{dm}^{-3}$. The same letter within the same dose of $\mathrm{P}$ fertilization indicates no significant difference (Tukey $5 \%, \mathrm{n}=5$ ). Bars represent standard error.

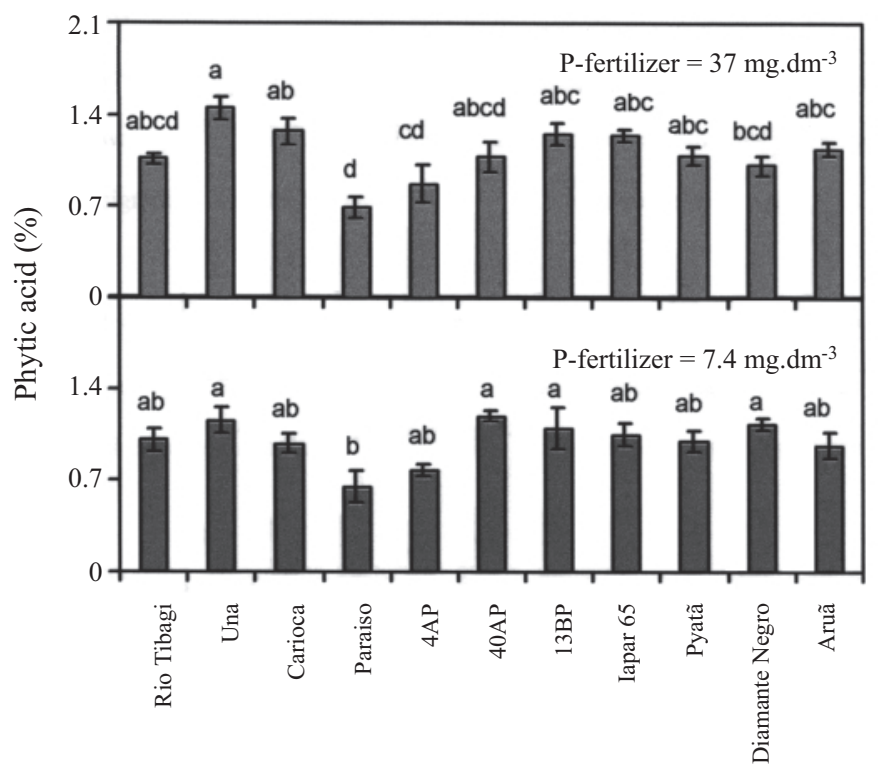

Genotypes

Figure 2. Phytate content in grains of bean genotypes grown under two doses of $\mathrm{P}$ fertilization. Phosphorus was applied at 7.4 and $37 \mathrm{mg} \cdot \mathrm{dm}^{-3}$. The same letter within the same dose of $\mathrm{P}$ fertilization indicates no significant difference (Tukey $5 \%, \mathrm{n}=5$ ). Bars represent standard error.
An important goal of breeding programs is to reduce phytate contents in grain without reducing the content of $\mathrm{P}$. Therefore, it is important to examine the fraction of $\mathrm{P}$ in the form of phytate. This parameter provides important information as to whether more or less seed $\mathrm{P}$ is being committed to phytate or to other forms of $\mathrm{P}$, and can thus provide clues as to the regulation of phytate synthesis. In fifty varieties of dry beans, the phytate fraction was reported to be between 54 and $82 \%$ of seed P (Lolas and Markakis, 1975). Under lower P fertilization, these values were highest in bean genotypes 40AP and Diamante negro (66.6 and $64.0 \%$, respectively), while the smallest fraction was found in Paraiso, where phytate comprised 40.4 $\%$ of grain P. Under the higher dose of fertilizer P, the fraction of $\mathrm{P}$ as phytate differed significantly between Una and Paraiso, which was found to be 72 and $47 \%$, respectively, although each did not differ from the other genotypes.

Inorganic $\mathrm{P}(\mathrm{Pi})$ is another important form of phosphorus in grains, although it is present at relatively low concentrations and thus constitutes a small fraction of the total $\mathrm{P}$ of grains. High levels of inorganic $\mathrm{P}$ are regarded as desirable from a nutritional standpoint. In addition, several studies point out that phytic acid metabolism is sensitive to cellular levels of Pi (Raboy and Dickinson, 1993). Under lower P supply, genotype 4AP presented the highest Pi content and 40AP the lowest, although they did not differ from the other genotypes. Under the higher dose of fertilizer P, Pi contents were different only between Paraiso $(0.033 \%)$ and Rio tibagi $(0.021 \%)$, as shown in figure 3 .

The fraction of seed $\mathrm{P}$ in the form of Pi was highest in Paraiso $(8 \%)$ at the higher dose of $\mathrm{P}$ fertilization, but did not differ from 4AP, Aruã, Diamante negro, Carioca, Una and Iapar-65. Rio tibagi presented the lowest (4\%) fraction of $\mathrm{P}$ as $\mathrm{Pi}$, although this value differed statistically only from Paraiso. With the lower dose of fertilizer P, Aruã, 4AP, Paraiso and Una did not differ and the Pi fraction averaged $6.7 \%$ in these genotypes. Usually, a close relationship between Pi and phytic acid during grain development and maturation is found, although in the case of maize mutants, reduced levels of phytic acid were accompanied by increasing levels of Pi (Raboy et al., 1990). In these bean genotypes, both Paraiso and 4AP, which had lower phytate contents, presented a tendency to have higher concentrations of $\mathrm{Pi}$ and a larger fraction of $\mathrm{P}$ as $\mathrm{Pi}$ than the other genotypes. 


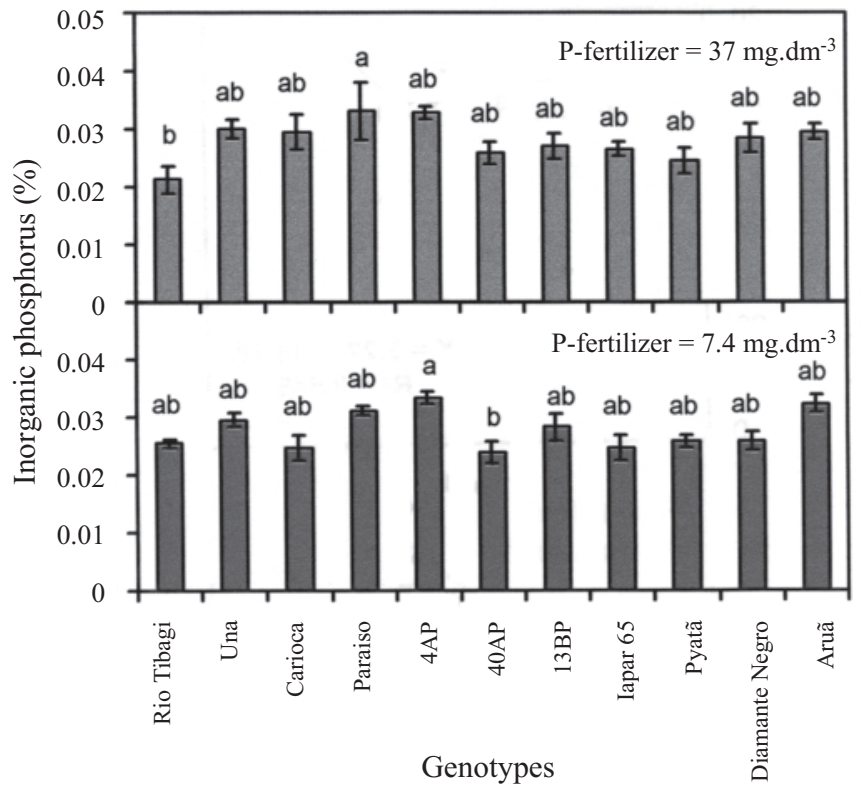

Figure 3. Inorganic phosphorus content in grains of bean genotypes grown under two doses of $\mathrm{P}$ fertilization. Phosphorus was applied at 7.4 and $37 \mathrm{mg} \cdot \mathrm{dm}^{-3}$. The same letter within the same dose of $\mathrm{P}$ fertilization indicates no significant difference (Tukey $5 \%, \mathrm{n}=5$ ). Bars represent standard error.

Evidence suggests that phytic acid synthesis may be induced in response to stimuli such as high Pi in grains or leaves (Raboy and Dickinson 1993). Increased phytic acid accumulation may be regulated by the activity of phosphoinositol kinase. This enzyme is located at an important branch point in the pathway leading to phytic acid, and Pi may directly increase the activity of this enzyme due to increased levels of 1L-myo-inositol-1-P and ATP (Chakrabarti and Biswas, 1981).

Breeding for reduced levels of phytic acid can result in undesirable effects, such as the reduction of $\mathrm{P}$, protein, and mineral elements in grain (Raboy et al., 1984b). Genotypes such as Paraiso, which display low phytate contents, without reduced $\mathrm{P}$ content, should prove useful in studies of the regulatory control of phytic acid synthesis in plants.

Variation in phytate content usually accounts for much of the variation in protein levels in grains. The interdependence between phytate and protein can be observed by the correlation between these two variables (Raboy et al., 1991). In this study, a higher correlation $(r=0.73)$ between phytate and protein was observed under the higher dose of $\mathrm{P}$ fertilization, while under the lower $\mathrm{P}$ dose no significant correlation was observed (Figure 4). The absence of a strong relationship between phytate and protein in this study was, in part, due to rather small variations in protein content. Nevertheless, these results are not unlike those found in the literature (Raboy et al., 1991; Chitra et al., 1995).

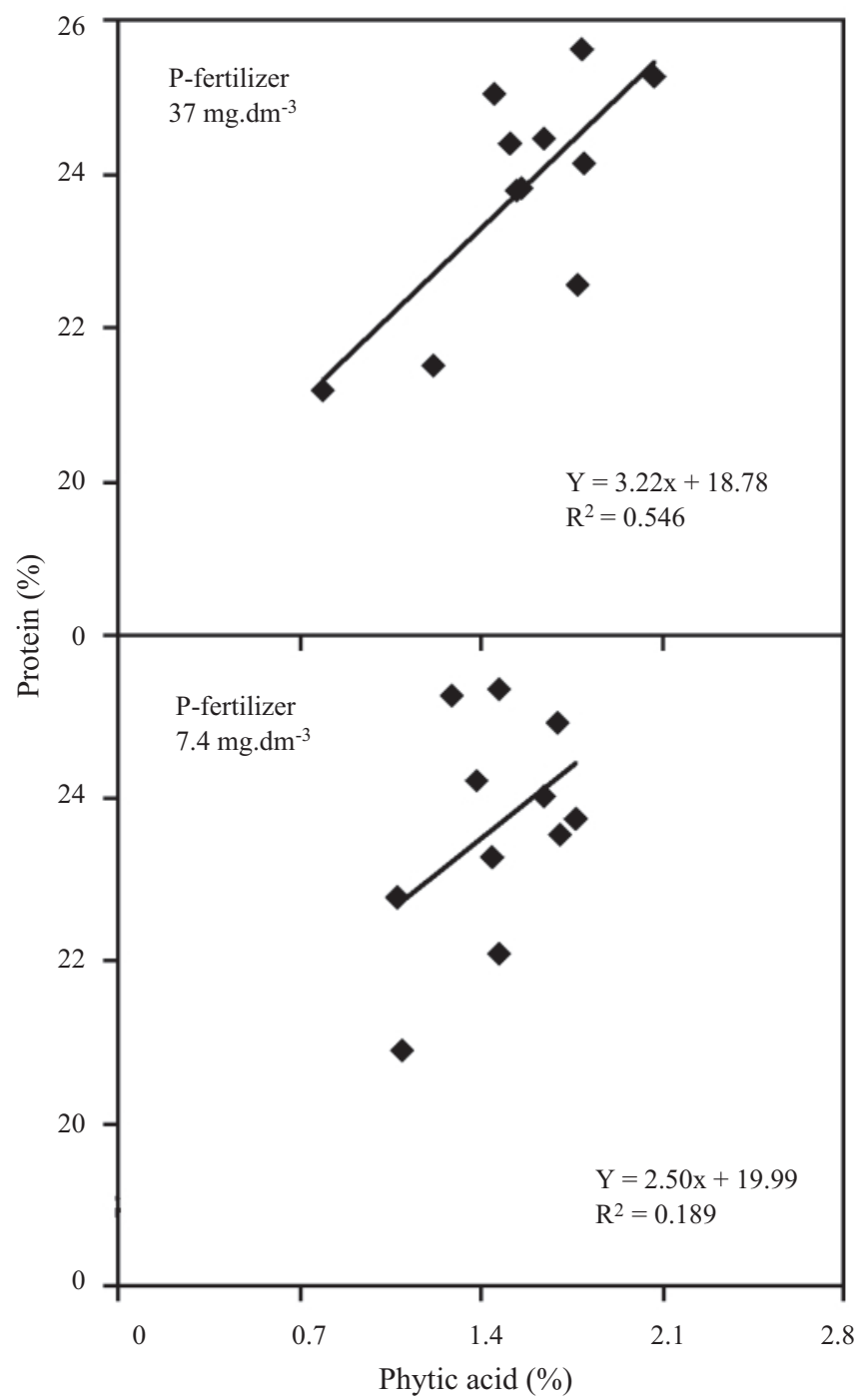

Figure 4. Correlation between protein and phytate contents in grains of bean genotypes grown under two doses of $\mathrm{P}$ fertilization. Phosphorus was applied at 7.4 and 37 $\mathrm{mg} \cdot \mathrm{dm}^{-3}$.

To examine the extent to which the uptake and translocation of phosphorus influenced the phytate content of the bean grains, the accumulation of $\mathrm{P}$ in the whole plant and grains, and the harvest index for $\mathrm{P}$ were also examined (table 1). No differences among genotypes were found at the lower dose of $\mathrm{P}$ fertilization. At higher doses of $\mathrm{P}$, Una and Paraiso, which contrasted with respect to phytate concentration, did not present significant differences in the amount of $\mathrm{P}$ accumulated in the whole plant and in the grains. However, differences were found between Rio tibagi and 4AP, although each did not differ from the other geno- 
types. Rio tibagi accumulated more $\mathrm{P}$ in grains and in the whole plant when compared with 4AP, which presented smaller amounts of $\mathrm{P}$ accumulation (table 1). The behavior of these last two genotypes is in agreement with results from Raboy and Dickinson (1984a), where it was shown that soybean varieties with higher amounts of leaf $\mathrm{P}$ presented correspondingly higher amounts of $\mathrm{P}$ in the seed. In the case of 4AP, the lower contents of $\mathrm{P}$ and phytate found in the seeds of this genotype (figure 1 and 2) can be almost entirely explained by the smaller quantities of $\mathrm{P}$ taken up by the plant and by a smaller harvest index for $\mathrm{P}$, when compared to the other genotypes.

The concentration of $\mathrm{P}$ in different parts of the plant can provide indications of how $\mathrm{P}$ is being used in the plant (Thung, 1990). However, very little differences were found among the genotypes with regard to $\mathrm{P}$ concentrations in the different plant parts. Differences were found only in roots and pods under higher doses of fertilizer P. In roots, Una showed a higher P content compared to Iapar-65, whereas in pods, the $\mathrm{P}$ content was higher in Rio tibagi compared with Diamante negro (table 2).

Although Rio tibagi and 4AP differed in the quantity of $\mathrm{P}$ amassed in the plant and grains (table 1) they did not differ with respect to $\mathrm{P}$ concentration in the various parts of the plant (table 2). This occurred because of the higher dry matter accumulation, both in the plant and grain of Rio tibagi (table 3). When comparing Una and Paraiso, the opposite occurred with regard to $\mathrm{P}$ contents and accumulation in the plants. No differences were found in the accumulation of $\mathrm{P}$ in the grains or entire plant (table 1), but a significant difference was found in the P concentration of the grain (figure 1). Again, this was caused by differences in dry matter accumulation, since the harvest index in Paraiso was greater than in Una (table 3).

In conclusion, genetic variability in phytate contents of seeds was observed, with values ranging from 0.7 to 1.48 $\%$, which is a range similar to that found in the literature (Lolas and Markakis, 1975; Raboy et al., 1994; Raboy et al., 1991; Ertl et al., 1998). Genotype 4AP was the only case in which lower P uptake and translocation apparently resulted in lower concentrations of $\mathrm{P}$ and phytate in the grain. In the other genotypes, no evidence was found to substantiate the hypothesis that seed phytate content could be regulated by the amount of P translocated to the seeds, since the harvest index for $\mathrm{P}$ was similar in these genotypes.

Table 1. Accumulation of phosphorus in grains and in whole plants (roots, leaves, stems, pods and grains) and harvest index for $\mathrm{P}$ in bean genotypes grown under two doses of P fertilization. Phosphorus was applied at 7.4 and $37 \mathrm{mg} . \mathrm{dm}^{-3}$.

\begin{tabular}{|c|c|c|c|c|c|c|}
\hline \multirow{3}{*}{ Genotypes } & \multicolumn{4}{|c|}{ Accumulation of $\mathrm{P}(\mathrm{mg})^{\mathrm{a}}$} & \multirow{2}{*}{\multicolumn{2}{|c|}{ Harvest index for $\mathrm{P}(\%)$}} \\
\hline & \multicolumn{2}{|c|}{ Grains } & \multicolumn{2}{|c|}{ Whole Plant } & & \\
\hline & 37.0 & 7.4 & 37.0 & 7.4 & 37.0 & 7.4 \\
\hline Rio tibagi & $65.01 \mathrm{a}$ & $49.23 \mathrm{a}$ & $88.42 \mathrm{a}$ & $69.89 \mathrm{a}$ & $72.71 \mathrm{ab}$ & $70.15 \mathrm{ab}$ \\
\hline Paraiso & $49.94 \mathrm{ab}$ & $50.61 \mathrm{a}$ & $65.28 \mathrm{ab}$ & $65.26 \mathrm{a}$ & $75.96 \mathrm{ab}$ & $77.40 \mathrm{ab}$ \\
\hline 4AP & $26.15 \mathrm{~b}$ & $34.29 \mathrm{a}$ & $39.76 \mathrm{~b}$ & $52.76 \mathrm{a}$ & $65.92 \mathrm{ab}$ & $65.02 \mathrm{~b}$ \\
\hline 40AP & $58.10 \mathrm{a}$ & $54.79 \mathrm{a}$ & $80.61 \mathrm{a}$ & $74.96 \mathrm{a}$ & $71.60 \mathrm{ab}$ & $71.99 \mathrm{ab}$ \\
\hline $13 \mathrm{BP}$ & $46.48 \mathrm{ab}$ & $59.90 \mathrm{a}$ & $66.17 \mathrm{ab}$ & $75.79 \mathrm{a}$ & $69.37 \mathrm{ab}$ & $79.05 \mathrm{a}$ \\
\hline Aruã & $41.86 \mathrm{ab}$ & $50.60 \mathrm{a}$ & $57.47 \mathrm{ab}$ & $70.24 \mathrm{a}$ & $72.34 \mathrm{ab}$ & $71.04 \mathrm{ab}$ \\
\hline
\end{tabular}

a Same letter within a column indicates no significant difference (Tukey $5 \%, n=5$ ). 
Table 2. Phosphorus contents in roots, shoots and pods in bean genotypes grown under two doses of P fertilization. Phosphorus was applied at 7.4 and $37 \mathrm{mg} . \mathrm{dm}^{-3}$.

\begin{tabular}{|c|c|c|c|c|c|c|}
\hline \multirow{2}{*}{ Genotypes } & \multicolumn{2}{|c|}{ Root } & \multicolumn{2}{|c|}{$\begin{array}{c}\mathrm{P} \text { content }(\%)^{\mathrm{a}} \\
\text { Shoot } \\
\text { dose of fertilizer } \mathrm{P}\left(\mathrm{mg} \cdot \mathrm{dm}^{-3}\right)\end{array}$} & \multicolumn{2}{|c|}{ Pod } \\
\hline & 37.0 & 7.4 & 37.0 & 7.4 & 37.0 & 7.4 \\
\hline Rio tibagi & $0.25 \mathrm{ab}$ & $0.20 \mathrm{a}$ & $0.17 \mathrm{a}$ & $0.17 \mathrm{a}$ & $0.06 \quad \mathrm{a}$ & $0.04 \mathrm{a}$ \\
\hline Una & $0.32 \mathrm{a}$ & $0.26 \mathrm{a}$ & $0.21 \mathrm{a}$ & $0.17 \mathrm{a}$ & $0.04 \mathrm{ab}$ & $0.03 \mathrm{a}$ \\
\hline Carioca & $0.24 \mathrm{ab}$ & $0.22 \mathrm{a}$ & $0.20 \mathrm{a}$ & $0.19 \mathrm{a}$ & $0.04 \mathrm{ab}$ & $0.03 \mathrm{a}$ \\
\hline Paraiso & $0.25 \mathrm{ab}$ & $0.25 \mathrm{a}$ & $0.18 \mathrm{a}$ & $0.17 \mathrm{a}$ & $0.04 \mathrm{ab}$ & $0.04 \mathrm{a}$ \\
\hline $4 \mathrm{AP}$ & $0.22 \mathrm{ab}$ & $0.21 \mathrm{a}$ & $0.17 \mathrm{a}$ & $0.17 \mathrm{a}$ & $0.04 \mathrm{ab}$ & $0.04 \mathrm{a}$ \\
\hline $40 \mathrm{AP}$ & $0.24 \mathrm{ab}$ & $0.19 \mathrm{a}$ & $0.18 \mathrm{a}$ & $0.19 \mathrm{a}$ & $0.03 \mathrm{ab}$ & $0.03 \mathrm{a}$ \\
\hline 13BP & $0.25 \mathrm{ab}$ & $0.25 \mathrm{a}$ & $0.18 \mathrm{a}$ & $0.15 \mathrm{a}$ & $0.03 \mathrm{ab}$ & $0.04 \mathrm{a}$ \\
\hline Iapar 65 & $0.20 \mathrm{~b}$ & $0.19 \mathrm{a}$ & $0.16 \mathrm{a}$ & $0.17 \mathrm{a}$ & $0.03 \mathrm{ab}$ & $0.03 \mathrm{a}$ \\
\hline Pyatã & $0.28 \mathrm{ab}$ & $0.22 \mathrm{a}$ & $0.24 \mathrm{a}$ & $0.19 \mathrm{a}$ & $0.03 \mathrm{ab}$ & $0.04 \mathrm{a}$ \\
\hline Diam.negro & $0.21 \mathrm{ab}$ & $0.22 \mathrm{a}$ & $0.15 \mathrm{a}$ & $0.19 \mathrm{a}$ & $0.02 \mathrm{~b}$ & $0.03 \mathrm{a}$ \\
\hline Aruã & $0.22 \mathrm{ab}$ & $0.21 \mathrm{a}$ & $0.15 \mathrm{a}$ & $0.16 \mathrm{a}$ & $0.04 \mathrm{ab}$ & $0.03 \mathrm{a}$ \\
\hline
\end{tabular}

a Same letter within a column indicates no significant difference (Tukey $5 \%, \mathrm{n}=5$ ).

Table 3. Dry matter accumulation in grains and in whole plants (roots, leaves, stems, pods and grains) and harvest index in bean genotypes grown under two doses of $\mathrm{P}$ fertilization. Phosphorus was applied at 7.4 and $37 \mathrm{mg} . \mathrm{dm}^{-3}$.

\begin{tabular}{|c|c|c|c|c|c|c|c|}
\hline \multirow[b]{2}{*}{ Genotypes } & \multicolumn{4}{|c|}{ Dry matter $(\mathrm{g})^{\mathrm{a}}$} & \multirow{2}{*}{\multicolumn{3}{|c|}{ Harvest index $(\%)$}} \\
\hline & \multicolumn{2}{|c|}{ Grain } & \multicolumn{2}{|c|}{$\begin{array}{c}\text { Whole plant } \\
\text { dose of fertilizer } \mathrm{P}\left(\mathrm{mg} \cdot \mathrm{dm}^{-3}\right)\end{array}$} & & & \\
\hline Rio tibagi & $12.16 \mathrm{a}$ & $9.64 \mathrm{a}$ & $27.89 \mathrm{a}$ & $24.20 \mathrm{a}$ & 42.87 & $\mathrm{~b}$ & $39.56 \mathrm{~b}$ \\
\hline Una & $7.58 \mathrm{ab}$ & $7.67 \mathrm{a}$ & $19.40 \mathrm{ab}$ & $18.27 \mathrm{a}$ & 38.06 & $\mathrm{~b}$ & $41.87 \mathrm{ab}$ \\
\hline $4 \mathrm{AP}$ & $5.42 \mathrm{~b}$ & $6.98 \mathrm{a}$ & $16.13 \mathrm{~b}$ & $19.84 \mathrm{a}$ & 33.60 & $\mathrm{~b}$ & $35.49 \mathrm{ab}$ \\
\hline 40AP & $11.22 \mathrm{ab}$ & $10.87 \mathrm{a}$ & $26.21 \mathrm{ab}$ & $24.21 \mathrm{a}$ & 42.16 & $\mathrm{~b}$ & $44.23 \mathrm{ab}$ \\
\hline $13 \mathrm{BP}$ & $8.11 \mathrm{ab}$ & $11.33 \mathrm{a}$ & $20.95 \mathrm{ab}$ & $23.62 \mathrm{a}$ & 37.54 & $\mathrm{~b}$ & $47.71 \mathrm{ab}$ \\
\hline Iapar 65 & $9.08 \mathrm{ab}$ & $11.49 \mathrm{a}$ & $21.87 \mathrm{ab}$ & $24.74 \mathrm{a}$ & 41.85 & $\mathrm{~b}$ & $46.07 \mathrm{ab}$ \\
\hline Pyatã & $11.21 \mathrm{ab}$ & $10.83 \mathrm{a}$ & $26.79 \mathrm{ab}$ & $26.34 \mathrm{a}$ & 42.16 & $\mathrm{~b}$ & $42.12 \mathrm{ab}$ \\
\hline
\end{tabular}

a Same letter within a column indicates no significant difference (Tukey $5 \%, n=5$ ).

In the case of the contrast between Una and Paraiso, where the latter presented a phytate concentration about half of that in Una, the differences in grain phytate content were, in part, due to differences in the use and metabolism of $\mathrm{P}$ within the grain. This can be inferred because the fraction of seed $\mathrm{P}$ in the form of phytate was significantly different between these two genotypes, and the fraction of $\mathrm{Pi}$ in Paraiso was also higher. However, metabolism of $\mathrm{P}$ in the grain cannot entirely explain the differences in phytate content of these two genotypes. Although the amount of P amassed by the plant and exported to the grain was not different between these two genotypes, the concentration of $\mathrm{P}$ in the grains of Paraiso was lower than in Una. This occurred because of the higher harvest index found in Paraiso (table 3). This also contributed to the lower concentrations of phytate in the seeds of Paraiso. 
Thus, in this study, differences in phytate content were caused by smaller $\mathrm{P}$ uptake and partitioning of $\mathrm{P}$ to the grain in one case, and by differences in dry matter accumulation and metabolism of $\mathrm{P}$ in the grain in another. The information reported here should prove useful both for bean breeding programs and for future studies related to the understanding of regulatory control of phytate synthesis in beans.

Acknowledgments: The authors are grateful to FAPESP for funding of this work and a fellowship granted to CMMC, and to CNPq for a fellowship granted to VAV, and to Dr. Jairo Lopes de Castro-IAC-Capão Bonito (SP), for providing the bean seeds.

\section{REFERENCES}

Buerkert A, Haake C, Ruckwied M, Marschner H (2001) Phosphorus application affects the nutritional quality of millet grain in the sahel. Field Crops Res. 57:223-235.

Chakrabarti S, Biswas BB (1981) Two forms of phosphoinositol kinase from germinating mung bean seeds. Phytochemistry 20:1815-1817.

Chen IW, Charalampous, F (1966) Biochemical studies on inositol: IX d-inositol 1-phosphate as intermediate in the biosynthesis of inositol from glucose 6-phosphate, and characteristics of two reactions in this biosynthesis. J. Biol. Chem. 241:2194-2199.

Cheryan M (1980) Phytic acid interations in food systems. Crit. Rev. Food Sci. Nutr. 13:297-335.

Coelho CMM (1998) Caracterização genética de dois acessos de feijoeiro com ênfase na qualidade de póscolheita. Piracicaba, Universidade de São Paulo. Dissertação de mestrado.

Chitra U, Vimala V, Singh U, Geervani P (1995) Variability in phytic acid content and protein digestibility of grain legumes. Plant Food Hum. Nutr. 47:163-172.

Ertl DS, Yuong KA, Raboy V (1998) Plant genetic approaches to phosphorus managment in agricultural production. J. Environ. Qual. 27:299-304.

Graf E, Empson KL, Eaton JW (1987) Phytic acid a natural antioxidant. J. Biol. Chem. 262:11647-11650.

Griffiths DW, Thomas TA (1981) Phytate and total phosphorus content of field beans (Vicia faba L.). J. Sci. Food Agri. 32:187-192.

Latta M, Eskin M (1980) A simple method for phytate determination. J. Agri. Food Chem. 28:1313-1315.

Lolas GM, Markakis P (1975) Phytic acid and other phosphorus compounds of beans (Phaseolus vulgaris L). J. Agri. Food Chem. 23:13-15.
Malavolta E, Vitti GC, Oliveira SA (1989) Avaliação do estado nutricional das plantas: princípios e aplicações. Associação Brasileira para Pesquisa da Potassa e do Fosfato, Piracicaba.

Mebrahtu T, Mohamed A, Elmi A (1997) Accumulation of phytate in vegetable type soybean genotypes harvested at four developmental stages. Plant Food Hum. Nutr. 50:179-187.

Miranda LCG, Oliveira TT, Mendonça RCS, Nagem TJN (1994) Variação dos teores de ácido fítico e fitatos em cultivares de soja. Ver. Ceres 41:623-628.

Parkinson M, Allen N (1975) A wet oxidation procedure suitable for the determination of nitrogen and mineral nutrients in biological material. Commun. Soil Sci. Plant Anal. 6:1-11.

Ribeiro MLL, Ida EI, Oliveira MCN (1999) Efeito da germinação de soja cv. BR-13 e Paraná sobre ácido fítico, fósforo total e inibidores de tripsina. Pesq. Agrop. Bras. 34:31-36.

Raboy V, Dickinson DB (1984a) Effect of phosphorus and zinc nutrition on soybean seed phytic acid and zinc. Plant Physiol. 75:1094-1098.

Raboy V, Dickinson DB, Below FE (1984b) Variation in seed total phosphorus, phytic acid, zinc, calcium, magnesium and protein among lines of Glycine max and $G$. Soja. Crop Sci. 24:431-434.

Raboy V, Dikinson DB, Neuffer MG (1990) A survey of maize kernel mutants for variation in phytic acid. Maydica 35:383-390.

Raboy V, Dickinson DB (1993) Phytic acid levels in seeds of Glicyne max and G. Soja as influenced by phosphorus status. Crop Sci. 33:1300-1305.

Raboy V, Noaman MM, Taylor GA Pickett SG (1991) Grain phytic acid and protein are highly correlated in winter wheat. Crop Sci. 31:631-635.

Reddy NR, Pierson MD, Sathe SK, Salunkhe DK (1989) Phytates in Cereals and Legumes, CRC Press, Boca Raton.

Santos JCP (1998) Estado nutricional do feijoeiro (Phaseolus vulgaris L.) e teores de nutrientes e fitatos nos grãos. Piracicaba, Universidade de São Paulo. Tese de doutorado.

Sarruge JR (1975) Soluções nutritivas. Summa Phytopathologica 1:231-233.

Thompson LU, Zhang L (1991) Phytic acid and minerals: effect on early markers of risk for mammary and colon carcinogenesis. Carcinogene 12:2041-2045.

Thung M (1990) Phosphorus: a limiting nutrient in bean (Phaseolus vulgaris L.) production in latin america and field screening for efficiency and response. Genet. Aspects Plant Miner. Nutr. 501-521. 